\title{
Discovering the Lost Reward: Critical Locations for Endocannabinoid Modulation of the Cortico-Striatal Loop That Are Implicated in Major Depression
}

\author{
Sari Goldstein Ferber ${ }^{1}$, Aron Weller ${ }^{1} \mathbb{D}$, Gal $_{\text {Yadid }}{ }^{2}$ and Alexander Friedman ${ }^{3, *}$ \\ 1 Department of Psychology and the Leslie and Susan Gonda (Goldschmied) Multidisciplinary Brain Research \\ Center, Bar Ilan University, Ramat Gan 5290002, Israel; sari.goldstein@biu.ac.il (S.G.F.); \\ aron.weller@biu.ac.il (A.W.) \\ 2 The Mina and Everard Goodman Faculty of Life Sciences and the Leslie and Susan Gonda (Goldschmied) \\ Multidisciplinary Brain Research Center, Bar Ilan University, Ramat Gan 5290002, Israel; \\ yadidg@mail.biu.ac.il \\ 3 Department of Biological Sciences, University of Texas at El Paso, El Paso, TX 79968, USA \\ * Correspondence: afriedman@utep.edu
}

Citation: Goldstein Ferber, S.; Weller,

A.; Yadid, G.; Friedman, A.

Discovering the Lost Reward: Critical Locations for Endocannabinoid Modulation of the Cortico-Striatal Loop That Are Implicated in Major Depression. Int. J. Mol. Sci. 2021, 22, 1867. https://doi.org/10.3390/ ijms22041867

Academic Editor: Miriam Melis

Received: 11 January 2021

Accepted: 10 February 2021

Published: 13 February 2021

Publisher's Note: MDPI stays neutral with regard to jurisdictional claims in published maps and institutional affiliations.

Copyright: (C) 2021 by the authors Licensee MDPI, Basel, Switzerland. This article is an open access article distributed under the terms and conditions of the Creative Commons Attribution (CC BY) license (https:/ / creativecommons.org/licenses/by/ $4.0 /)$.

\begin{abstract}
Depression, the most prevalent psychiatric disorder in the Western world, is characterized by increased negative affect (i.e., depressed mood, cost value increase) and reduced positive affect (i.e., anhedonia, reward value decrease), fatigue, loss of appetite, and reduced psychomotor activity except for cases of agitative depression. Some forms, such as post-partum depression, have a high risk for suicidal attempts. Recent studies in humans and in animal models relate major depression occurrence and reoccurrence to alterations in dopaminergic activity, in addition to other neurotransmitter systems. Imaging studies detected decreased activity in the brain reward circuits in major depression. Therefore, the location of dopamine receptors in these circuits is relevant for understanding major depression. Interestingly, in cortico-striatal-dopaminergic pathways within the reward and cost circuits, the expression of dopamine and its contribution to reward are modulated by endocannabinoid receptors. These receptors are enriched in the striosomal compartment of striatum that selectively projects to dopaminergic neurons of substantia nigra compacta and is vulnerable to stress. This review aims to show the crosstalk between endocannabinoid and dopamine receptors and their vulnerability to stress in the reward circuits, especially in corticostriatal regions. The implications for novel treatments of major depression are discussed.
\end{abstract}

Keywords: endocannabinoid receptors; dopamine; synaptic plasticity; depression; striosomes; ventral tegmental area (VTA)

\section{Major Depression: Diagnostic Criteria, Prevalence and Etiology}

Major Depressive Disorder is one of the most prevalent mental disorders in the Western world and it is the third leading cause of disability in the world. The prevalence rates range, for most countries, between $8 \%$ and $12 \%$ of the population [1]. According to the World Health Organization, major depression also shows the greatest disability levels and the largest aligned costs for the community and individuals among the mental and behavioral disorders [2,3]. According to the 5th edition of the Diagnostic and Statistical Manual of Mental Disorders (DSM-5) [4], a major depressive episode is defined as a period of 2 weeks or longer during which there is either depressed mood or loss of interest or pleasure (i.e., anhedonia) and four additional symptoms reflecting changes in activity, e.g., psychomotor agitation, retardation or fatigue, change in sleep patterns and suicidality. This disorder is complex, and its etiology, which may include social and psychological factors such as stressful or traumatic events [5,6], inflammation and microbiome [7-9], in addition to epigenetic and genetic ones and age-related factors [10-13], remains unclear to date [14]. Depressive symptoms may be reduced within several weeks after the start of conventional 
antidepressants, but treatment resistance concerns one-third of the patients who fail to achieve recovery. Hence, the current pharmacological treatment of major depression is accordingly limited. Depression-induced reduction in seeking rewarding experiences and in satisfaction with a rewarding experience in humans as well as in animal models led the scientific community to place the motivational/anhedonic characteristics in the center of the efforts to understand major depression. This involves a focus on the brain reward circuits and underscores the importance of the dopamine (DA) receptors within these circuits [15-24].

In this review, we suggest understanding major depression as an erroneous computation of cost and reward values produced by reduced sensitivity to reward. We also aim to show that the endocannabinoid and DA systems interacting within the reward circuit and the critical locations of the DA and CB1 receptors open a window of opportunities for pharmacological treatment with cannabinoids in treatment-resistant cases of major depression.

\section{Dopamine and Major Depression}

\subsection{Location of DA Activity within Subcortical Circuits}

Since the 1960s, depression has been associated with dysfunctions of the serotonin (5-HT)- and norepinephrine-circuits [25-27], and the first choice for treatment became SSRIs and SNRIs, followed by the development of advanced pharmacological compounds aimed at the reuptake of serotonin and norepinephrine. However, research using neuroimaging, pharmacological, and electrophysiological methods in humans and animal models has shown distinct dopaminergic abnormalities in major depression [28-33]; for a review, see [34].

Some studies [35] showed that selective inhibition of DA neurons in the ventral tegmental area (VTA), as well as exposure to chronic mild stress (CMS), results in depressionlike phenotypes that are normalized by selective activation of the mesolimbic DA system that mediates reward value [36,37]. Additionally, drugs that enhance DA signaling can have antidepressant effects in individuals experiencing major depression [38], further implicating DA dysfunction in major depression. Moreover, pharmacological and other interventions that block or modulate dopaminergic activity can induce or increase depressive-like symptoms in currently depressed or remitted individuals $[39,40]$ suggesting the need to identify a regulated optimal level of DA to be targeted in these novel treatments.

The corticolimbic DA circuit, with excitatory glutamatergic projections from the medial prefrontal cortex to the basal ganglia, is involved in motivational processes, assignment of reward and cost value [41] and in valence, including subjective value [42] It is susceptible to psychosocial stress [43], which, in turn, is a major trigger for the onset, occurrence and reoccurrence of many psychopathologies including major depression. DA transmission is essential for attribution of incentive salience [44] and prediction of reward occurrence [45]. DA neurons fire in response to reward-associated cues and in cases of positive discrepancy between the reward obtained and the reward expected [45-48]. Accordingly, depression was associated with reduced reward-related functional connectivity between the medial prefrontal cortex and the striatum [49].

\subsection{Top-Down Bottom-Up Cortical DA Connectivity with Subcortical Circuits}

Emerging evidence suggests that the VTA-medial prefrontal cortex (PFC) pathway serves an opposite function to the VTA-NAc pathway, demonstrating the differential role of distinct VTA DA neuron populations in response to rewarding vs. aversive stimuli in the context of depression [30]. This may be responsible for the negative perceptual bias in major depression, implying a negative experience of positive and neutral events.

Additionally, decreased dopaminergic activity is shown in endophenotypes of major depression, such as anhedonia and reduced motivation, and this downregulation appears to originate via hyperexcitation of the infralimbic PFC-basolateral amygdala-ventral pal- 
lidum (VP) pathway and possibly via disrupted synaptic plasticity in the ventral subiculum of the hippocampus-nucleus accumbens pathway [16].

\subsection{The Excitation-Inhibition Imbalance}

The interfered modulation of excitation-inhibition balance in major depression is further evident in an imbalance in the excitatory function of glutamate vs. the inhibitory function of gamma-aminobutyric acid (GABA) within the striatum. Further inhibitory functions are evident in the dopaminergic positive effect on the organism due to lower metabotropic glutamate receptor activation and expression [50]. Preclinical and clinical evidence implicates glutamatergic system impairments in mood disorders such as major depressive disorder.

Interestingly, over the last 20 years, ketamine, an antagonist of the $N$-methyl-Daspartate receptor, an ionotropic glutamate receptor, has been shown to have antidepressant properties. Specifically, there is a substantial body of literature comprising anecdotal material and descriptions of uncontrolled and randomized controlled trials addressing the use of sub-anesthetic doses of ketamine for the off-label treatment of major depressive episodes [51-53]. Furthermore, the functional changes in glutamatergic neurotransmission have been associated with neuronal morphological remodeling, dendritic retraction, and synaptic reorganization, particularly within cortical areas [54]. It is suggested that in major depression the stimulation which inhibits GABA release upregulates the glutamatergic activity and secondarily the dopaminergic pathways [55]. This points to the importance of the excitation-inhibition balance in DA circulation for better understanding of major depression and assigning appropriate pharmacological treatment to this disorder.

In addition, there appears to be an optimal level of DA receptor firing that may be beneficial for the depressive behavioral and emotional profile, as both attenuation and enhanced dopaminergic neural activity have been found to be beneficial for psychiatric disorders. Recent reports suggest that regulation rather than diminution or increases in dopaminergic level is required for the treatment of major depression [56]. This suggests a view of major depression as a cortico-striatal disconnection or spiral error of connectivity between those regions in major depression.

\section{The Reward Circuits and Major Depression}

\subsection{The Striatum and the Mesolimbic Area}

The DSM defines anhedonia as diminished interest or pleasure in response to stimuli that were previously perceived as rewarding before the development of the disorder $[4,16]$. The dopaminergic neurons of the VTA are connected to mesolimbic pathways often regarded as the "reward pathway". The center of this network is the striatum. VTA dopaminergic neuronal activity results in higher levels of DA in the striatum guiding motivation and effort, and any abnormalities in dopaminergic signaling could lead to inappropriate and non-gratified reward-seeking behavior $[57,58]$. This dopaminergic signaling from the VTA is crucial for the functioning of the dorsal and ventral striatum [59], regions associated with motivational experience and motivated behaviors including expectation for rewards $[60,61]$. Accordingly, research showed that dams from a rat model of depression are less rewarded by pups compared to control dams, and this is associated with less DA spillover and metabolism, as measured by microdialysis [19].

The cortico-striatal circuit in neuroimaging of humans includes the nucleus accumbens, the ventral medial caudate, and the rostroventral putamen [62], and the central regions activating it are the frontostriatal pathways [62-66]. These pathways are activated by dopaminergic projections from midbrain nuclei (e.g., the ventral tegmental area) to subcortical regions central to the evaluation of the reward (e.g., the ventral striatum, including the nucleus accumbens), and finally leading to cortical decision-making and the modulation of emotionality (e.g., the orbitofrontal cortex, medial prefrontal cortex, anterior cingulate cortex). PET and fMRI studies show that primary (e.g., sensory) and secondary rewards (e.g., monetary rewards, reward receipt, reward properties guessing) increase 
striatal activity [62,67-70]. Down-regulation or blocking reward system leads to decreased motivation as well as decreased goal-directed cognitions and behaviors. Behaviorally, this is demonstrated by increased withdrawal and negative emotionality (e.g., depressive states and anhedonia) [71].

In recent years, down-regulation of the reward system has been related to major depression symptoms, especially reduced motivation and pro-hedonic behaviors, in humans and rats [72,73]. Alterations in the reward circuits may persist after remission in major depression, pointing to the need to pharmacologically address the neural connectivity in the reward circuits to better treat this disorder [74], especially through receptors which crosstalk with the dopaminergic pathways [71]. Interestingly, a rat model of depression exhibits sub-sensitivity in cocaine-seeking behavior, whereas antidepressant treatment raised their cocaine-induced DA release to the level of controls, resulting in increased cocaine-seeking behavior [75]. Further research is needed to investigate the shift from ventral and medial interneurons to the lateral compartment of the striatum including studies of the striatum gradients [76-82].

\subsection{The Striosomal Compartment of Striatum}

The striatum has multiple organizing dimensions, including physical three-dimensional regions along ventral-dorsal, medial-lateral and anterior-posterior axes [82-84], and its interneurons [85] as well as the projection neurons that give rise to the direct and indirect basal ganglia output pathways [86-90]. A third organizational dimension is represented by the striosomal compartment and the surrounding matrix compartment (Figure 1) [91]. Striatal organization was discovered in 1978 [91]. One compartment of the striatum was called striosomes-bodes in the striatum and the second compartment was called the matrix. It was demonstrated that striosomes receive a distinct set of inputs and outputs [92-94]. Major striosomal inputs are prelimbic and infralimbic districts of the prefrontal cortex as well as a orbitofrontal cortex; major outputs of striosomes are dopaminergic neurons of Substantia nigra pars compacta (SNC) (predominant source of reward) and lateral habenula (predominant source of cost) [95-97]. Multiple evidence demonstrates that striosomes have molecular and RNA expression that are different from the matrix [98,99].

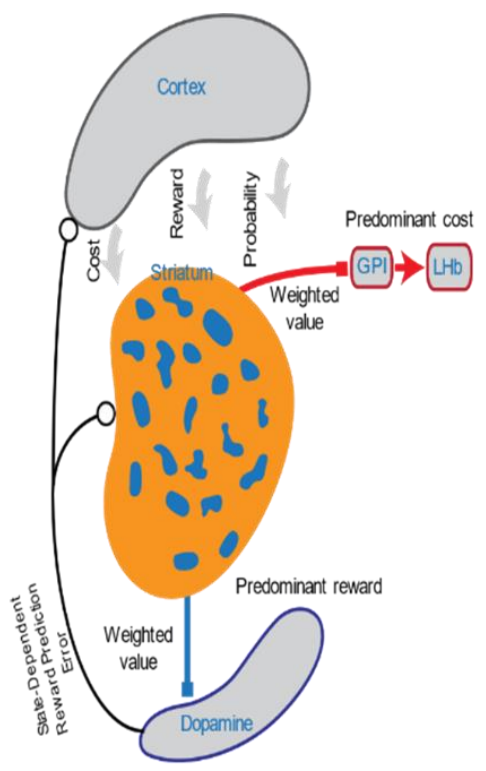

Figure 1. Dorsomedial striatum (DMS) striosomes lie at the center of the Cortico-Striosomal, Lateral Habenula, Dopaminergic Evaluation Circuit. Striosomes encode the subjective value of reward, cost, and uncertainty, and integrate these signals. DMS striosomes selectively project to the SNC (predominant source of reward) and Lateral Habenula. 
Of particular behavioral relevance and importance for depression, striosomes receive selective inputs from cortical and subcortical regions related to the limbic system [92,99], and send selective outputs to the lateral habenula $(\mathrm{LHb})[96,100,101]$ and dopaminergic neurons of SNC [95,99,102-104], which then ultimately feedback to striatum [105-107], including striosomes. This input and output connectivity converts striosomes to a crossroad between limbic districts of cortex and the dopaminergic system. Striosomes, by virtue of their input to $\mathrm{LHb}$ and dopaminergic neurons of $\mathrm{SNC}$, could influence the state-dependent modulation of dopaminergic neurons that may be essential for depression.

Recent cell-specific gene expression profiling has demonstrated a striosome-predominant pattern of presynaptic Cannabinoid Receptor 1 (CB1R) expression. The CB1R is abundantly expressed in striatal striosomes and striosome-dendron bouquets of the substantia nigra. Dense CB1R-expressing striosomal fibers extend the substantia nigra pars reticulata, and colocalize with bundles of ventrally extending dendrites of DA-containing SNC neurons [95]. This again shows the relevance of the striosomal circuit for depression.

Aberrant striosomal activity is related to shifts in the dynamic balance of excitation and inhibition in a prefronto-striosomal circuit, resulting in excitation of striosomes in the dorsomedial striatum. The affected circuit elements include neurons of the medial prefrontal cortex and their putative targets in the dorsomedial striatum, including both putative striosomal projection neurons and fast-spiking interneurons. Further radically altered dynamics are apparent in the activity of the fast-spiking interneurons (FSIs), in animals engaged in cost-benefit choices. Importantly, brains of suicide victims, an event often highly associated with major depression, exhibit preferentially increased striosomal expression of prodynorphin, relative to control individuals [108].

\section{The Endocannabinoid System and Major Depression}

The endocannabinoid system (ECS) includes: 1. Endocannabinoids (endogenous ligands), currently characterized: 2-arachidonoylglycerol (2-AG), anandamide ( $\mathrm{N}$-arachidonoy lethanolamine (AEA)), virodhamine (O-arachidonoyl ethanolamine), and $\mathrm{N}$-arachidonoyldopamine (NADA); 2. Particular enzymes that either degrade or synthesize them; 3. Cannabinoid receptors: the two main ones are CB1R and CB2R; G-protein coupled metabotropic receptors) [109]. Other cannabinoid receptors include G-protein-coupled receptor 55 (GPR55) and transient receptor potential vanilloid type 1 (TRPV1) [110-113]. CB1R are found in many brain areas and neuron types. CB2R are expressed mainly in the periphery, and the CB2R in the brain $[114,115]$ are not on neurons but rather on microglia [116]. The endocannabinoids exhibit differential affinity in binding CB1R and CB2R as well as to GPR55, GPR18 and GPR119, TRPV1, peroxisome proliferator-activated receptors (PPARs) and glycine receptors [117].

CB1Rs were found in the striatum among other areas. These receptors are also expressed in brain locations of efferent dopaminergic terminals [118]. They were reported to affect excitatory and inhibitory glutamate and GABA synaptic activity, respectively, through cortical afferents and dopaminergic activity. In the dorsal striatum, the ECS exerts long-term presynaptic regulation. The complex role of the ECS in the striatal area is evident in the activation of metabotropic glutamate receptors that can stimulate 2-AG production through activation of phospholipase C [119]. CB1R have been implicated in mediating stress responses in numerous studies, while CB2R are not mentioned frequently in this context [120]. Nevertheless, CB2R have recently been implicated in stress, anxiety and depression [121,122] and their role has yet to be fully characterized.

Chronic blocking of CB1R in animals produces anhedonia-like reactions [123]. Animal models also show that compromised CB1R signaling is associated with reduction in sensitivity to reward (sucrose) [124]. The exogenous stimulation of CB1R by exogenous cannabinoids elevated DA release through 2-AG- signaling and CB1R binding [125]. By producing a balanced inhibition on both GABAergic and glutamatergic synapses, the endocannabinoid signaling is able to enhance DA function with the resulting increase in motivation and reward-seeking behavior, as shown in Figure 2 [126]. Due to the potential 
of the endocannabinoid receptors to increase sensitivity to a reward in the behavioral and neural levels, their location within the reward circuits is crucial for cases of major depression lacking this sensitivity and pro-hedonic behavior related to it [127].

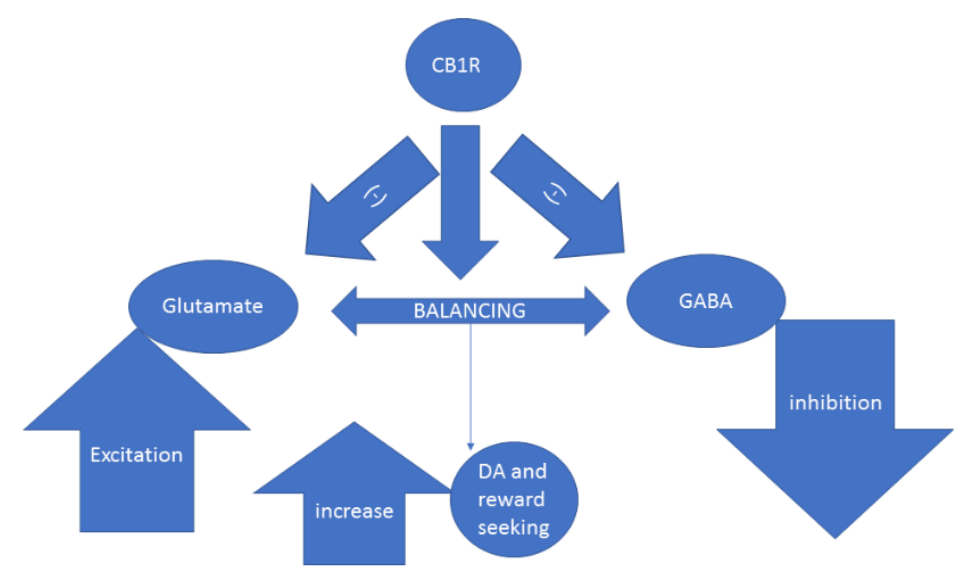

Figure 2. Activation of $\mathrm{CB} 1 \mathrm{R}$ in the striatum facilitates glutamatergic and GABAergic balance through inhibition of overshooting which, in turn, increases DA neural activity and reward seeking behavior, pointing to its critical location.

Recently, we discussed the epigenetic fragility of the ECS [128] and the bidirectional function of the system under stress [129]. Moreover, histone deacetylase (HDAC) inhibitors were found to interact with the ECS on the epigenetic level in preclinical studies of depression and chronic stress effects $[130,131]$, suggesting that the crosstalk between ECS and DA receptors may be located at the epigenetic level. The interference of this healthy crosstalk on the epigenetic level may involve further risks for the development of depression, especially under stressful conditions. This has further implications for the development of pharmacogenomics to treat major depression in order to target the availability of ECS-DA receptors beyond monoamine transporters [128].

\section{The Crosstalk between Dopamine, Striosomes and Endocannabinoid Receptors}

CB1R mRNA signal in the ventral and dorsal striatum responds to DA inputs in medium spiny neurons (MSNs) of the striatum [132]. CB1R mRNAs are expressed in both DA 1 receptor (D1R) and D2R-containing cells [133]. Moreover, CB1R were found at the same locations with D2R in pre- and postsynaptic medium spiny neurons of the striatum [134]. It has been shown that endogenous cannabinoids and D2R work in concert and facilitate each other's neural activity in the brain. Specifically, D2R activity caused the elicitation of anandamide production, which, in turn, was followed by CB1Rs activity in striatum [135].

Accordingly, CB1Rs located on both the GABAergic medium spiny neurons (MSNs) and corticostriatal projections $[136,137]$ are part of the striatal control [138,139], modulating arousal states, as shown in MSNs in animal models of excitotoxicity [140] and Huntington's disease [141-143]. In addition, it has been found that CB1R located in corticostriatal sites differentially protected D1R-MSNs but not D2R-MSNs from cortex-elicited damage by inhibiting glutamatergic activity. Thus, CB1R in corticostriatal projections controls D1RMSNs of the mouse dorsal striatum by altering glutamatergic output [132]. In summary, the mutual influences between glutamatergic and dopaminergic signaling are considered an important mechanism in major depression [58,144]. Thus, endocannabinoids are an important component that may lead the scientific community towards a better understanding of the potent effects by- and on-dopaminergic activity in the striatum. 


\section{The CB1 Crosstalk with the Striosomal Activity on the Molecular Level}

It has been demonstrated that striosomes can be on-off gates on cortico-striosomal circuits [41,43]. An essential level of selectivity is a molecular level underlying this circuit activity, which includes the CB1R. Striosomes, while carrying the supporting value of reward, which is distorted in major depression, produce an enriched CB1R expression via the dendron and through the LHb pathway, suggesting a critical junction for treating major depression.

Importantly, Friedman and colleagues [42] found a correlation between the activity of the striosomal populations and the valence discriminations achieved by the mice, and these signals and correlations were sensitive to motivational value, as tested by outcome devaluation. Collectively, this and previous studies of striosomal function [41,42] suggest that striosomes could serve as a subjective value filter via integration of cortical task information and motivational state on route to the DA system.

\section{Vulnerability of Dopamine and Endocannabinoid Systems within the Reward Circuits: Implications for Major Depression}

The treatment of major depression may need to take into account stressful conditions and the reaction to stress within the reward circuits. Inhibition of anti-stress signaling systems within neurocircuits in VP and lateral hypothalamus reduces signaling towards the DA mesolimbic system [126]. The stress effects have a direct influence on DA function, as glucocorticoids modulate the firing of DA neurons [145]. Note that regions involved in the stress reaction are compromised by glucocorticoid mediated atrophy (i.e., hippocampus, PFC) [146] and they are also key regulators of mesolimbic and mesocortical dopaminergic pathways [145] indirectly affecting the reward circuits. The ECS is affected by stress and it only partially recovers with positive inputs [129]. However, recent reports show that the ECS, especially the CB1R, buffers the detrimental impact of stress on reward sensitivity $[147,148]$. Therefore, the treatment of major depression may need to target stress resilience to reach optimal levels of DA circulation for the subjective experience of reward in the individuals suffering from major depression. More research on the modulation of DA receptors by the endocannabinoid system under stress is warranted. In this regard, measures of PV neurons in the striatum and striatal choline acetyltransferase (ChAT) interneurons, which are sensitive to DA, may emphasize additional critical locations for DA modulation in major depression [107,149-153]. Thus, treatment with cannabidiol (CBD) may need to be based on clinical trials for determining titration rates and to provide the option of monitoring the treatment.

Depression is a psychiatric disorder that preferentially affects women, and women are at increased risk for developing depression. Since there are sex differences in CB1R availability [154], future research should examine DA-CB1R receptor crosstalk in postpartum depression and sex-dependent DA-CB1R crosstalk in Major Depression, issues still to be clarified.

\section{Insufficiency of Past and Current Pharmacological Treatments for Major Depression: Implications for Novel Treatment with CBD}

The first line of pharmacological treatment for depression, such as serotonin reuptake inhibitors (SSRIs), addresses the monoaminergic systems but is limited by a high resistance rate (e.g., $\sim 40-60 \%$ of patients do not reach remission) and delayed onset of therapeutic effects as weeks of treatment are necessary [155-157]. This delay particularly underscores the need for fast-acting medication. Anhedonia and reduced motivation, some of the main features of major depression, have been suggested as a cause of treatment resistant conditions $[72,127,158-160]$. This points to the potential therapeutic benefits of treatment with CBD, given its acute positive effects in animal models [161,162].

There is a growing body of knowledge documenting that second-generation antidepressants, such as SSRIs, are not effective in treating positive affect deficits, such as motivation and reward-related cognitive impairment in major depression [163,164]. More- 
over, these antidepressants act through 5-HT2C receptors which bind serotonin and inhibit dopaminergic activity. The regulation, rather than inhibition, of dopaminergic pathways may contribute to the suggested low efficacy of SSRIs in treatment-resistant cases due to the necessary firing rate and number of spikes per burst in the reward circuits for the treatment of major depression [165-167]. This might underlie the resistance of major depression treated by SSRIs.

Dysregulation in DA expression is also observed in patients treated with typical antipsychotics [168,169], which block D2R [170], leading to DA depletion and a lack of improvement in the ventral striatum [58]. In contrast, the augmentation of treatment with SSRIs by antipsychotic drugs has been shown to increase the expression of DA and the antidepressant effect of SSRIs, thus reflecting the central role of DA expression availability in major depression. This has been shown in humans and animal models and has been approved by the FDA [171]. In addition, ketamine is known to have a strong positive and fast onset efficacy for treating depression; however, it also shows short-term dissociative side effects [16]. Interestingly, ketamine, similarly to atypical antipsychotics, works though modulation of dopaminergic activity in the reward circuits. Due to its problematic side effects, other DA-modulating drugs should be explored.

The literature suggests that $\mathrm{CBD}$ acts through DA and serotonin receptors within the mesolimbic areas, especially the VTA and NAc. GABAergic neurons are also implied in this therapeutically effective crosstalk [172]. Specifically, it was found that CBD acts in two phases as a DA partial agonist of D2R [172,173] and attenuating dopaminergic overproduction. This suggests the regulatory capacity of CBD. As potentiating anandamide neurotransmission is among CBD's multiple modes of action [174], its effects on the CB1R can also indirectly improve depressive conditions through regulating excitation-inhibition balance (Figure 1). At a molecular level, regulation of p70S6 kinase (p70S6K) downstream activity by CBD has been found to reverse the effects of amphetamine through dopaminergic pathways [175-177]. CBD is an agonist of 5HT1A [178] and DA receptors by the inhibition of cellular reuptake and hydrolysis of the endocannabinoid anandamide [172,179]. The CBD effects on DA-5HT crosstalk in the mesolimbic area may be regulated through the ventral hippocampal area and its connections with other limbic and frontolimbic regions [180]. Thus, this cortico-striatal loop is shown to lead to emotional and cognitive modulation of neuropsychiatric disorders, including major depression. Interestingly, several approved antidepressant treatments upregulate (in most studies) CB1R and DA receptors [117,181-184]. However, given the high prevalence of treatment resistance, the next generation of pharmacological treatments may need to target the availability of these receptors through pharmacogenomic developments [128].

\section{For Further Research}

New molecular investigations which include RNA sequencing as well as the detection of other critical circuits which function in parallel to the striatum, such as the thalamus, amygdala and the hippocampus, may support the description of a wider scope of relevant locations of CB1R mediating reward in major depression. The involvement of cortical layers in decreasing the sensitivity to reward in major depression and their functionality under CBD treatment may elucidate the critical role of CB1R and pave the way towards future treatment of major depression. Furthermore, the striosomal-CB1R effects, reviewed here, in the rodent's dorsomedial "associative" striatum, show the striatal region as affected by chronic stress, along with the prefrontal cortex itself [76,185]. While striosomes are not uniform across the striatum in terms of their input-output connections, or in terms of their cell-type constituents, different sub-regions of striatum are selectively affected by chronic stress, thus having complex implications for major depression which warrant further studies [76]. 


\section{Conclusions}

We showed recent accumulating evidence on the regulation of dopaminergic signaling within the reward circuits by ECS receptors. This has been shown at neural and anatomic levels, as well as at the cellular level. We have also shown that abnormal activity in the reward circuits characterizes major depression. The location of CB1 and DA receptors within the reward circuits, especially the striatal location, is crucial for consideration and development of the next generation of pharmacological treatment of major depression. The crosstalk between CB1, DA and glutamate receptors within the mesolimbic area, especially within the striatum, is accompanied by the stimulation of 5HT in this region, and thus has an upgrading effect for treatment of major depression. Furthermore, we suggested a complex role of CB1R through GABAergic and glutamatergic activity to avoid overshooting or decreasing the dopaminergic activity by stimulation of CB1R. Beyond targeting monoamine transporters, research on pharmacogenomics targeting CB1R availability for treatment of depression and anxiety is warranted [128]. As the ECS is a modulatory and homeostatic network and protects the brain from extreme excitatory or inhibitory conditions, it is suggested that treatment with CBD holds promise for the treatment of major depression. In light of the prevalence of major depression as well as the number of people resistant to current pharmacological treatment, clinical trials of the effects of CBD are warranted.

Author Contributions: All authors contributed substantially to this review paper and approved the final version. All authors have read and agreed to the published version of the manuscript.

Funding: This review was not supported by any funding agency.

Institutional Review Board Statement: Not applicable.

Informed Consent Statement: Not applicable.

Acknowledgments: Research in AW's lab is supported by the Israel Science Foundation (grant \#1781/16) and the Israel Ministry of Science and Technology (grant \#3-15689). The funding sources had no influence on the content of this review.

Conflicts of Interest: The authors declare no conflict of interest.

\section{References}

1. Kessler, R.C.; Bromet, E.J. The Epidemiology of Depression Across Cultures. Annu. Rev. Public Health 2013, 34, 119-138. [CrossRef]

2. Collins, P.Y.; Patel, V.; Joestl, S.S.; March, D.; Insel, T.R.; Daar, A.S.; Bordin, I.A.; Costello, E.J.; Durkin, M.; Fairburn, C.G.; et al. Grand challenges in global mental health. Nat. Cell Biol. 2011, 475, 27-30. [CrossRef] [PubMed]

3. James, S.L.; Abate, D.; Abate, K.H.; Abay, S.M.; Abbafati, C.; Abbasi, N.; Abbastabar, H.; Abd-Allah, F.; Abdela, J.; Abdelalim, A.; et al. Global, regional, and national incidence, prevalence, and years lived with disability for 354 diseases and injuries for 195 countries and territories, 1990-2017: A systematic analysis for the Global Burden of Disease Study. Lancet 2018, 392, 1789-1858. [CrossRef]

4. American Psychiatric Association. Diagnostic and Statistical Manual of Mental Disorders; American Psychiatric Association Publishing: Washington, DC, USA, 2013. [CrossRef]

5. Athira, K.V.; Bandopadhyay, S.; Samudrala, P.K.; Naidu, V.; Lahkar, M.; Chakravarty, S. An Overview of the Heterogeneity of Major Depressive Disorder: Current Knowledge and Future Prospective. Curr. Neuropharmacol. 2020, 18, 168-187. [CrossRef] [PubMed]

6. Ehlers, C.L.; Frank, E.; Kupfer, D.J. Social Zeitgebers and Biological Rhythms. Arch. Gen. Psychiatry 1988, 45, 948-952. [CrossRef] [PubMed]

7. Visentin, A.P.V.; Colombo, R.; Scotton, E.; Fracasso, D.S.; Da Rosa, A.R.; Branco, C.S.; Salvador, M. Targeting InflammatoryMitochondrial Response in Major Depression: Current Evidence and Further Challenges. Oxidative Med. Cell. Longev. 2020, 2020, 1-20. [CrossRef]

8. Yang, Z.; Li, J.; Gui, X.; Shi, X.; Bao, Z.; Han, H.; Li, M.D. Updated review of research on the gut microbiota and their relation to depression in animals and human beings. Mol. Psychiatry 2020, 25, 2759-2772. [CrossRef]

9. Beurel, E.; Toups, M.; Nemeroff, C.B. The Bidirectional Relationship of Depression and Inflammation: Double Trouble. Neuron 2020, 107, 234-256. [CrossRef] [PubMed]

10. Xu, Q.; Jiang, M.; Gu, S.; Wang, F.; Yuan, B. Early Life Stress Induced DNA Methylation of Monoamine Oxidases Leads to Depressive-Like Behavior. Front. Cell Dev. Biol. 2020, 8, 8. [CrossRef] 
11. Coelho, F.M.D.C.; Pinheiro, R.T.; Silva, R.A.; de Ávila Quevedo, L.; Souza, L.D.D.M.; Castelli, R.D.; De Matos, M.B.; Pinheiro, K.A.T. Major Depressive Disorder during Teenage Pregnancy: Socio-demographic, Obstetric and Psychosocial Correlates. Rev. Bras. Psiquiatr. 2013, 35, 51-56. [CrossRef]

12. Menezes, I.C.; Baes, C.V.W.; Lacchini, R.; Juruena, M.F. Genetic biomarkers for differential diagnosis of major depressive disorder and bipolar disorder: A systematic and critical review. Behav. Brain Res. 2019, 358, 29-38. [CrossRef]

13. Faye, C.; McGowan, J.C.; Denny, C.A.; David, D.J. Neurobiological Mechanisms of Stress Resilience and Implications for the Aged Population. Curr. Neuropharmacol. 2018, 16, 234-270. [CrossRef] [PubMed]

14. McIntosh, A.M.; Sullivan, P.F.; Lewis, C.M. Uncovering the Genetic Architecture of Major Depression. Neuron 2019, 102, 91-103. [CrossRef]

15. Wohlschläger, A.; Karne, H.; Jordan, D.; Lowe, M.J.; Jones, S.E.; Anand, A. Spectral Dynamics of Resting State fMRI Within the Ventral Tegmental Area and Dorsal Raphe Nuclei in Medication-Free Major Depressive Disorder in Young Adults. Front. Psychiatry 2018, 9, 163. [CrossRef] [PubMed]

16. Belujon, P.; Grace, A.A. Dopamine System Dysregulation in Major Depressive Disorders. Int. J. Neuropsychopharmacol. 2017, 20, 1036-1046. [CrossRef] [PubMed]

17. Blum, K.; Chen, A.L.C.; Oscar-Berman, M.; Chen, T.J.H.; Lubar, J.; White, N.; Lubar, J.; Bowirrat, A.; Braverman, E.; Schoolfield, J.; et al. Generational Association Studies of Dopaminergic Genes in Reward Deficiency Syndrome (RDS) Subjects: Selecting Appropriate Phenotypes for Reward Dependence Behaviors. Int. J. Environ. Res. Public Health 2011, 8, 4425-4459. [CrossRef] [PubMed]

18. Dremencov, E.; Gispan-Herman, I.; Rosenstein, M.; Mendelman, A.; Overstreet, D.H.; Zohar, J.; Yadid, G. The serotonin-dopamine interaction is critical for fast-onset action of antidepressant treatment: In vivo studies in an animal model of depression. Prog. Neuro Psychopharmacol. Biol. Psychiatry 2004, 28, 141-147. [CrossRef]

19. Lavi-Avnon, Y.; Weller, A.; Finberg, J.P.M.; Gispan-Herman, I.; Kinor, N.; Stern, Y.; Schroeder, M.; Gelber, V.; Bergman, S.Y.; Overstreet, D.H.; et al. The reward system and maternal behavior in an animal model of depression: A microdialysis study. Psychopharmacology 2007, 196, 281-291. [CrossRef]

20. Yadid, G.; Friedman, A. Dynamics of the dopaminergic system as a key component to the understanding of depression. Prog. Brain Res. 2008, 172, 265-286. [CrossRef]

21. Dremencov, E.; Newman, M.E.; Kinor, N.; Blatman-Jan, G.; Schindler, C.J.; Overstreet, D.H.; Yadid, G. Hyperfunctionality of serotonin-2C receptor-mediated inhibition of accumbal dopamine release in an animal model of depression is reversed by antidepressant treatment. Neuropharmacology 2005, 48, 34-42. [CrossRef]

22. Zangen, A.; Nakash, R.; Overstreet, D.; Yadid, G. Association between depressive behavior and absence of serotonin-dopamine interaction in the nucleus accumbens. Psychopharmacology 2001, 155, 434-439. [CrossRef]

23. Dremencov, E.; Weizmann, Y.; Kinor, N.; Gispan-Herman, I.; Yadid, G. Modulation of Dopamine Transmission by 5HT2C and 5HT3 Receptors: A Role in the Antidepressant Response. Curr. Drug Targets 2006, 7, 165-175. [CrossRef]

24. Schwerdt, H.N.; Amemori, K.; Gibson, D.J.; Stanwicks, L.L.; Yoshida, T.; Bichot, N.P.; DeSimone, R.; Langer, R.; Cima, M.J.; Graybiel, A.M. Dopamine and beta-band oscillations differentially link to striatal value and motor control. Sci. Adv. 2020, 6, eabb9226. [CrossRef] [PubMed]

25. Bunney, W.E. Norepinephrine in Depressive Reactions. Arch. Gen. Psychiatry 1965, 13, 483-494. [CrossRef]

26. Schildkraut, J.J.; Gordon, E.K.; Durell, J. Catecholamine metabolism in affective disorders: I. J. Psychiatr. Res. 1965, 3, 213-228. [CrossRef]

27. Coppen, A. The Biochemistry of Affective Disorders. Br. J. Psychiatry 1967, 113, 1237-1264. [CrossRef]

28. Belujon, P.; Grace, A.A. Restoring Mood Balance in Depression: Ketamine Reverses Deficit in Dopamine-Dependent Synaptic Plasticity. Biol. Psychiatry 2014, 76, 927-936. [CrossRef]

29. Tye, K.M.; Deisseroth, K. Optogenetic investigation of neural circuits underlying brain disease in animal models. Nat. Rev. Neurosci. 2012, 13, 251-266. [CrossRef] [PubMed]

30. Chaudhury, D.; Walsh, J.J.; Friedman, A.K.; Juarez, B.; Ku, S.M.; Koo, J.W.; Ferguson, D.; Tsai, H.-C.; E Pomeranz, L.; Christoffel, D.J.; et al. Rapid regulation of depression-related behaviours by control of midbrain dopamine neurons. Nat. Cell Biol. 2012, 493, 532-536. [CrossRef]

31. Savitz, J.; Hodgkinson, C.A.; Martin-Soelch, C.; Shen, P.-H.; Szczepanik, J.; Nugent, A.; Herscovitch, P.; Grace, A.A.; Goldman, D.; Drevets, W.C. The Functional DRD3 Ser9Gly Polymorphism (rs6280) Is Pleiotropic, Affecting Reward as Well as Movement. PLoS ONE 2013, 8, e54108. [CrossRef]

32. Chang, C.-H.; Grace, A.A. Amygdala-Ventral Pallidum Pathway Decreases Dopamine Activity After Chronic Mild Stress in Rats. Biol. Psychiatry 2014, 76, 223-230. [CrossRef] [PubMed]

33. Moreines, J.L.; Owrutsky, Z.L.; A Grace, A. Involvement of Infralimbic Prefrontal Cortex but not Lateral Habenula in Dopamine Attenuation After Chronic Mild Stress. Neuropsychopharmacology 2016, 42, 904-913. [CrossRef] [PubMed]

34. Friedman, A.; Friedman, Y.; Dremencov, E.; Yadid, G. VTA Dopamine Neuron Bursting is Altered in an Animal Model of Depression and Corrected by Desipramine. J. Mol. Neurosci. 2008, 34, 201-209. [CrossRef]

35. Tye, K.M.; Mirzabekov, J.J.; Warden, M.R.; Ferenczi, E.A.; Tsai, H.-C.; Finkelstein, J.; Kim, S.-Y.; Adhikari, A.; Thompson, K.R.; Andalman, A.S.; et al. Dopamine neurons modulate neural encoding and expression of depression-related behaviour. Nat. Cell Biol. 2012, 493, 537-541. [CrossRef] 
36. Friedman, A.; Frankel, M.; Flaumenhaft, Y.; Merenlender, A.; Pinhasov, A.; Feder, Y.; Taler, M.; Gil-Ad, I.; Abeles, M.; Yadid, G. Programmed Acute Electrical Stimulation of Ventral Tegmental Area Alleviates Depressive-Like Behavior. Neuropsychopharmacology 2008, 34, 1057-1066. [CrossRef] [PubMed]

37. Gazit, T.; Friedman, A.; Lax, E.; Samuel, M.; Zahut, R.; Katz, M.; Abraham, L.; Tischler, H.; Teicher, M.; Yadid, G. Programmed deep brain stimulation synchronizes VTA gamma band field potential and alleviates depressive-like behavior in rats. Neuropharmacology 2015, 91, 135-141. [CrossRef]

38. Dunlop, B.W.; Nemeroff, C.B. The Role of Dopamine in the Pathophysiology of Depression. Arch. Gen. Psychiatry 2007, 64, 327-337. [CrossRef]

39. Paret, C.; Kluetsch, R.; Zaehringer, J.; Ruf, M.; Demirakca, T.; Bohus, M.; Ende, G.; Schmahl, C. Alterations of amygdala-prefrontal connectivity with real-time fMRI neurofeedback in BPD patients. Soc. Cogn. Affect. Neurosci. 2016, 11, 952-960. [CrossRef]

40. Hasler, G.; Fromm, S.; Carlson, P.J.; Luckenbaugh, D.A.; Waldeck, T.; Geraci, M.; Roiser, J.P.; Neumeister, A.; Meyers, N.; Charney, D.S.; et al. Neural Response to Catecholamine Depletion in Unmedicated Subjects With Major Depressive Disorder in Remission and Healthy Subjects. Arch. Gen. Psychiatry 2008, 65, 521-531. [CrossRef]

41. Friedman, A.; Homma, D.; Gibb, L.G.; Amemori, K.-I.; Rubin, S.J.; Hood, A.S.; Riad, M.H.; Graybiel, A.M. A Corticostriatal Path Targeting Striosomes Controls Decision-Making under Conflict. Cell 2015, 161, 1320-1333. [CrossRef]

42. Friedman, A.; Hueske, E.; Drammis, S.M.; Arana, S.E.T.; Nelson, E.D.; Carter, C.W.; Delcasso, S.; Rodriguez, R.X.; Lutwak, H.; DiMarco, K.S.; et al. Striosomes Mediate Value-Based Learning Vulnerable in Age and a Huntington's Disease Model. Cell 2020, 183, 918-934.e49. [CrossRef] [PubMed]

43. Friedman, A.; Homma, D.; Bloem, B.; Gibb, L.G.; Amemori, K.-I.; Hu, D.; Delcasso, S.; Truong, T.F.; Yang, J.; Hood, A.S.; et al. Chronic Stress Alters Striosome-Circuit Dynamics, Leading to Aberrant Decision-Making. Cell 2017, 171, 1191-1205.e28. [CrossRef] [PubMed]

44. Berridge, K.C. The debate over dopamine's role in reward: The case for incentive salience. Psychopharmacology 2007, 191, 391-431. [CrossRef]

45. Schott, B.H.; Minuzzi, L.; Krebs, R.M.; Elmenhorst, D.; Lang, M.; Winz, O.H.; Seidenbecher, C.I.; Coenen, H.H.; Heinze, H.-J.; Zilles, K.; et al. Mesolimbic Functional Magnetic Resonance Imaging Activations during Reward Anticipation Correlate with Reward-Related Ventral Striatal Dopamine Release. J. Neurosci. 2008, 28, 14311-14319. [CrossRef] [PubMed]

46. Rizvi, S.J.; Pizzagalli, D.A.; Sproule, B.A.; Kennedy, S.H. Assessing anhedonia in depression: Potentials and pitfalls. Neurosci. Biobehav. Rev. 2016, 65, 21-35. [CrossRef]

47. Treadway, M.T.; Zald, D.H. Reconsidering anhedonia in depression: Lessons from translational neuroscience. Neurosci. Biobehav. Rev. 2011, 35, 537-555. [CrossRef] [PubMed]

48. Thomsen, K.R.; Whybrow, P.C.; Kringelbach, M.L. Reconceptualizing anhedonia: Novel perspectives on balancing the pleasure networks in the human brain. Front. Behav. Neurosci. 2015, 9, 49. [CrossRef]

49. Rupprechter, S.; Romaniuk, L.; Series, P.; Hirose, Y.; Hawkins, E.; Sandu, A.-L.; Waiter, G.D.; McNeil, C.J.; Shen, X.; A Harris, M.; et al. Blunted medial prefrontal cortico-limbic reward-related effective connectivity and depression. Brain 2020, 143, 1946-1956. [CrossRef]

50. Mao, L.-M.; Wang, J.Q. Alterations in mGlu5 receptor expression and function in the striatum in a rat depression model. J. Neurochem. 2018, 145, 287-298. [CrossRef]

51. Lener, M.S.; Kadriu, B.; Zarate, C.A. Ketamine and Beyond: Investigations into the Potential of Glutamatergic Agents to Treat Depression. Drugs 2017, 77, 381-401. [CrossRef]

52. Corriger, A.; Pickering, G. Ketamine and depression: A narrative review. Drug Des. Dev. Ther. 2019, 13, 3051-3067. [CrossRef] [PubMed]

53. Kraus, C.; Rabl, U.; Vanicek, T.; Carlberg, L.; Popovic, A.; Spies, M.; Bartova, L.; Gryglewski, G.; Papageorgiou, K.; Lanzenberger, R.; et al. Administration of ketamine for unipolar and bipolar depression. Int. J. Psychiatry Clin. Pract. 2017, 21, 2-12. [CrossRef] [PubMed]

54. Li, N.; Liu, R.-J.; Dwyer, J.M.; Banasr, M.; Lee, B.; Son, H.; Li, X.-Y.; Aghajanian, G.; Duman, R.S. Glutamate N-methyl-D-aspartate Receptor Antagonists Rapidly Reverse Behavioral and Synaptic Deficits Caused by Chronic Stress Exposure. Biol. Psychiatry 2011, 69, 754-761. [CrossRef] [PubMed]

55. Salagre, E.; Grande, I.; Solé, B.; Sanchez-Moreno, J.; Vieta, E. Vortioxetine: A new alternative for the treatment of major depressive disorder. Rev. Psiquiatr. Salud Ment. 2018, 11, 48-59. [CrossRef]

56. Grace, A.A. Dysregulation of the dopamine system in the pathophysiology of schizophrenia and depression. Nat. Rev. Neurosci. 2016, 17, 524-532. [CrossRef] [PubMed]

57. Arias-Carrión, Ó.; Pöppel, E. Dopamine, learning, and reward-seeking behavior. Acta Neurobiol. Exp. 2007, 67, 481-488. Available online: https://www.researchgate.net/profile/Ernst_Poeppel/publication/5531082_Dopamine_learning_and_rewardseeking_behavior/links/54db98010cf23fe133ad631e.pdf (accessed on 15 March 2020).

58. Szczypiński, J.J.; Gola, M. Dopamine dysregulation hypothesis: The common basis for motivational anhedonia in major depressive disorder and schizophrenia? Rev. Neurosci. 2018, 29, 727-744. [CrossRef]

59. Piray, P.; den Ouden, H.E.; van der Schaaf, M.E.; Toni, I.; Cools, R. Dopaminergic Modulation of the Functional Ventrodorsal Ar-chitecture of the Human Striatum. Cereb. Cortex 2017, 27, 485-495. [PubMed] 
60. Knutson, B.; Westdorp, A.; Kaiser, E.; Hommer, D. FMRI Visualization of Brain Activity during a Monetary Incentive Delay Task. Neuroimage 2000, 12, 20-27. [CrossRef]

61. Benningfield, M.M.; Blackford, J.U.; Ellsworth, M.E.; Samanez-Larkin, G.R.; Martin, P.R.; Cowan, R.L.; Zald, D.H. Caudate responses to reward anticipation associated with delay discounting behavior in healthy youth. Dev. Cogn. Neurosci. 2014, 7, 43-52. [CrossRef] [PubMed]

62. Haber, S.N.; Knutson, B. The Reward Circuit: Linking Primate Anatomy and Human Imaging. Neuropsychopharmacology 2009, 35, 4-26. [CrossRef]

63. Berridge, K.C.; E Robinson, T.; Aldridge, J.W. Dissecting components of reward: 'Liking', 'wanting', and learning. Curr. Opin. Pharmacol. 2009, 9, 65-73. [CrossRef]

64. Kringelbach, M.L.; Berridge, K.C. Towards a functional neuroanatomy of pleasure and happiness. Trends Cogn. Sci. 2009, 13, 479-487. [CrossRef]

65. Schultz, W. Multiple reward signals in the brain. Nat. Rev. Neurosci. 2000, 1, 199-207. [CrossRef]

66. Schultz, W.; Tremblay, L.; Hollerman, J.R. Reward Processing in Primate Orbitofrontal Cortex and Basal Ganglia. Cereb. Cortex 2000, 10, 272-284. [CrossRef]

67. Takahashi, T.; Yúcel, M.; Lorenzetti, V.; Nakamura, K.; Whittle, S.; Walterfang, M.; Suzuki, M.; Pantelis, C.; Allen, N.B. Midline brain structures in patients with current and remitted major depression. Prog. Neuro Psychopharmacol. Biol. Psychiatry 2009, 33, 1058-1063. [CrossRef] [PubMed]

68. Knutson, B.; Taylor, J.; Kaufman, M.; Peterson, R.; Glover, G. Distributed Neural Representation of Expected Value. J. Neurosci. 2005, 25, 4806-4812. [CrossRef] [PubMed]

69. Small, D.M.; Zatorre, R.J.; Dagher, A.; Evans, A.C.; Jones-Gotman, M. Changes in brain activity related to eating chocolate: From pleasure to aversion. Brain 2001, 124, 1720-1733. [CrossRef]

70. Richards, J.M.; Plate, R.C.; Ernst, M. A systematic review of fMRI reward paradigms used in studies of adolescents vs. adults: The impact of task design and implications for understanding neurodevelopment. Neurosci. Biobehav. Rev. 2013, 37, 976-991. [CrossRef]

71. Nusslock, R.; Alloy, L.B. Reward processing and mood-related symptoms: An RDoC and translational neuroscience perspective. J. Affect. Disord. 2017, 216, 3-16. [CrossRef] [PubMed]

72. Alloy, L.B.; Olino, T.; Freed, R.D.; Nusslock, R. Role of Reward Sensitivity and Processing in Major Depressive and Bipolar Spectrum Disorders. Behav. Ther. 2016, 47, 600-621. [CrossRef] [PubMed]

73. Argyropoulos, S.V.; Nutt, D.J. Anhedonia revisited: Is there a role for dopamine-targeting drugs for depression? J. Psychopharmacol. 2013, 27, 869-877. [CrossRef]

74. Pechtel, P.; Dutra, S.J.; Goetz, E.L.; Pizzagalli, D.A. Blunted reward responsiveness in remitted depression. J. Psychiatr. Res. 2013, 47, 1864-1869. [CrossRef]

75. Roth-Deri, I.; Friedman, A.; Abraham, L.; Lax, E.; Flaumenhaft, Y.; Dikshtein, Y.; Yadid, G. Antidepressant treatment facilitates dopamine release and drug seeking behavior in a genetic animal model of depression. Eur. J. Neurosci. 2009, 30, 485-492. [CrossRef]

76. Dias-Ferreira, E.; Sousa, J.C.; Melo, I.; Morgado, P.; Mesquita, A.R.; Cerqueira, J.J.; Costa, R.M.; Sousa, N. Chronic Stress Causes Frontostriatal Reorganization and Affects Decision-Making. Science 2009, 325, 621-625. [CrossRef] [PubMed]

77. Burton, A.C.; Nakamura, K.; Roesch, M.R. From ventral-medial to dorsal-lateral striatum: Neural correlates of reward-guided decision-making. Neurobiol. Learn. Mem. 2015, 117, 51-59. [CrossRef]

78. Thomason, M.E.; Marusak, H.A. Within-subject neural reactivity to reward and threat is inverted in young adolescents. Psychol. Med. 2017, 47, 1549-1560. [CrossRef]

79. Yang, J.-H.; Liao, R.-M. Dissociable contribution of nucleus accumbens and dorsolateral striatum to the acquisition of risk choice behavior in the rat. Neurobiol. Learn. Mem. 2015, 126, 67-77. [CrossRef] [PubMed]

80. Jacquet, M.; Lecourtier, L.; Cassel, R.; Loureiro, M.; Cosquer, B.; Escoffier, G.; Migliorati, M.; Cassel, J.-C.; Roman, F.; Marchetti, E. Dorsolateral striatum and dorsal hippocampus: A serial contribution to acquisition of cue-reward associations in rats. Behav. Brain Res. 2013, 239, 94-103. [CrossRef]

81. Thapa, R.; Gruber, A.J. Lesions of ventrolateral striatum eliminate lose-shift but not win-stay behaviour in rats. Neurobiol. Learn. Mem. 2018, 155, 446-451. [CrossRef]

82. Cox, J.; Witten, I.B. Striatal circuits for reward learning and decision-making. Nat. Rev. Neurosci. 2019, 20, 482-494. [CrossRef] [PubMed]

83. Stalnaker, T.A.; Calhoon, G.G.; Ogawa, M.; Roesch, M.R.; Schoenbaum, G. Neural correlates of stimulus-response and responseoutcome associations in dorsolateral versus dorsomedial striatum. Front. Integr. Neurosci. 2010, 4, 12. [CrossRef] [PubMed]

84. Voorn, P.; Vanderschuren, L.J.; Groenewegen, H.J.; Robbins, T.W.; Pennartz, C.M. Putting a spin on the dorsal-ventral divide of the striatum. Trends Neurosci. 2004, 27, 468-474. [CrossRef]

85. Tepper, J.M.; Bolam, J.P. Functional diversity and specificity of neostriatal interneurons. Curr. Opin. Neurobiol. $2004,14,685-692$. [CrossRef] [PubMed]

86. Dudman, J.T.; Gerfen, C.R. The Basal Ganglia. In The Rat Nervous System, 4th ed.; Elsevier Inc.: Amsterdam, The Netherlands, 2015; pp. 391-440. [CrossRef] 
87. Kreitzer, A.C.; Berke, J.D. Investigating striatal function through cell-type-specific manipulations. Neuroscience 2011, 198, 19-26. [CrossRef]

88. Miyamoto, Y.; Nagayoshi, I.; Nishi, A.; Fukuda, T. Three divisions of the mouse caudal striatum differ in the proportions of dopamine D1 and D2 receptor-expressing cells, distribution of dopaminergic axons, and composition of cholinergic and GABAergic interneurons. Brain Struct. Funct. 2019, 224, 2703-2716. [CrossRef] [PubMed]

89. Parker, J.G.; Marshall, J.D.; Ahanonu, B.; Wu, Y.-W.; Kim, T.H.; Grewe, B.F.; Zhang, Y.; Li, J.Z.; Ding, J.B.; Ehlers, M.D.; et al. Diametric neural ensemble dynamics in parkinsonian and dyskinetic states. Nat. Cell Biol. 2018, 557, 177-182. [CrossRef]

90. Surmeier, D.J.; Ding, J.; Day, M.; Wang, Z.; Shen, W. D1 and D2 dopamine-receptor modulation of striatal glutamatergic signaling in striatal medium spiny neurons. Trends Neurosci. 2007, 30, 228-235. [CrossRef]

91. Graybiel, A.M.; Ragsdale, C.W. Histochemically distinct compartments in the striatum of human, monkeys, and cat demonstrated by acetylthiocholinesterase staining. Proc. Natl. Acad. Sci. USA 1978, 75, 5723-5726. [CrossRef]

92. Eblen, F.; Graybiel, A. Highly restricted origin of prefrontal cortical inputs to striosomes in the macaque monkey. J. Neurosci. 1995, 15, 5999-6013. [CrossRef]

93. Gerfen, C.R. The neostriatal mosaic: Compartmentalization of corticostriatal input and striatonigral output systems. Nat. Cell Biol. 1984, 311, 461-464. [CrossRef]

94. Smith, J.B.; Klug, J.R.; Ross, D.L.; Howard, C.D.; Hollon, N.G.; Ko, V.I.; Hoffman, H.; Callaway, E.M.; Gerfen, C.R.; Jin, X. Genetic-Based Dissection Unveils the Inputs and Outputs of Striatal Patch and Matrix Compartments. Neuron 2016, 91, 1069-1084. [CrossRef]

95. Crittenden, J.R.; Tillberg, P.W.; Riad, M.H.; Shima, Y.; Gerfen, C.R.; Curry, J.; Housman, D.E.; Nelson, S.B.; Boyden, E.S.; Graybiel, A.M. Striosome-dendron bouquets highlight a unique striatonigral circuit targeting dopamine-containing neurons. Proc. Natl. Acad. Sci. USA 2016, 113, 11318-11323. [CrossRef]

96. Hong, S.; Amemori, S.; Chung, E.; Gibson, D.J.; Amemori, K.-I.; Graybiel, A.M. Predominant Striatal Input to the Lateral Habenula in Macaques Comes from Striosomes. Curr. Biol. 2019, 29, 51-61.e5. [CrossRef] [PubMed]

97. Watabe-Uchida, M.; Zhu, L.; Ogawa, S.K.; Vamanrao, A.; Uchida, N. Whole-Brain Mapping of Direct Inputs to Midbrain Dopamine Neurons. Neuron 2012, 74, 858-873. [CrossRef]

98. Graybiel, A.M. Neurotransmitters and neuromodulators in the basal ganglia. Trends Neurosci. 1990, 13, 244-254. [CrossRef]

99. Crittenden, J.R.; Graybiel, A.M. Basal Ganglia Disorders Associated with Imbalances in the Striatal Striosome and Matrix Compartments. Front. Neuroanat. 2011, 5, 59. [CrossRef]

100. Rajakumar, N.; Elisevich, K.; Flumerfelt, B.A. Compartmental origin of the striato-entopeduncular projection in the rat. J. Comp. Neurol. 1993, 331, 286-296. [CrossRef] [PubMed]

101. Stephenson-Jones, M.; Kardamakis, A.A.; Robertson, B.; Grillner, S. Independent circuits in the basal ganglia for the evaluation and selection of actions. Proc. Natl. Acad. Sci. USA 2013, 110, E3670-E3679. [CrossRef]

102. Fujiyama, F.; Sohn, J.; Nakano, T.; Furuta, T.; Nakamura, K.C.; Matsuda, W.; Kaneko, T. Exclusive and common targets of neostriatofugal projections of rat striosome neurons: A single neuron-tracing study using a viral vector. Eur. J. Neurosci. 2011, 33, 668-677. [CrossRef] [PubMed]

103. McGregor, M.M.; McKinsey, G.L.; Girasole, A.E.; Bair-Marshall, C.J.; Rubenstein, J.L.; Nelson, A.B. Functionally Distinct Connectivity of Developmentally Targeted Striosome Neurons. Cell Rep. 2019, 29, 1419-1428.e5. [CrossRef]

104. Evans, R.C.; Twedell, E.L.; Zhu, M.; Ascencio, J.; Zhang, R.; Khaliq, Z.M. Functional Dissection of Basal Ganglia Inhibitory Inputs onto Substantia Nigra Dopaminergic Neurons. Cell Rep. 2020, 32. [CrossRef]

105. Haber, S.N.; Fudge, J.L.; McFarland, N.R. Striatonigrostriatal Pathways in Primates Form an Ascending Spiral from the Shell to the Dorsolateral Striatum. J. Neurosci. 2000, 20, 2369-2382. [CrossRef]

106. Lerner, T.N.; Shilyansky, C.; Davidson, T.J.; Evans, K.E.; Beier, K.T.; Zalocusky, K.A.; Crow, A.K.; Malenka, R.C.; Luo, L.; Tomer, R.; et al. Intact-Brain Analyses Reveal Distinct Information Carried by SNc Dopamine Subcircuits. Cell 2015, 162, 635-647. [CrossRef] [PubMed]

107. Tritsch, N.X.; Sabatini, B.L. Dopaminergic Modulation of Synaptic Transmission in Cortex and Striatum. Neuron 2012, 76, 33-50. [CrossRef] [PubMed]

108. Hurd, Y.L.; Herman, M.M.; Hyde, T.M.; Bigelow, L.B.; Weinberger, D.R.; E Kleinman, J. Prodynorphin mRNA expression is increased in the patch vs matrix compartment of the caudate nucleus in suicide subjects. Mol. Psychiatry 1997, 2, 495-500. [CrossRef] [PubMed]

109. Kano, M.; Ohno-Shosaku, T.; Hashimotodani, Y.; Uchigashima, M.; Watanabe, M. Endocannabinoid-Mediated Control of Synaptic Transmission. Physiol. Rev. 2009, 89, 309-380. [CrossRef]

110. Piomelli, D. The molecular logic of endocannabinoid signalling. Nat. Rev. Neurosci. 2003, 4, 873-884. [CrossRef] [PubMed]

111. Marco, E.M.; Echeverry-Alzate, V.; López-Moreno, J.A.; Giné, E.; Peñasco, S.; Viveros, M.P. Consequences of early life stress on the expression of endocannabinoid-related genes in the rat brain. Behav. Pharmacol. 2014, 25, 547-556. [CrossRef] [PubMed]

112. Di Marzo, V. Endocannabinoid signaling in the brain: Biosynthetic mechanisms in the limelight. Nat. Neurosci. 2010, 14, 9-15. [CrossRef] [PubMed]

113. Hillard, C.J. The Endocannabinoid Signaling System in the CNS. In International Review of Neurobiology; Academic Press Inc.: Cambridge, MA, USA, 2015; Volume 125, pp. 1-47. [CrossRef] 
114. Onaivi, E.S.; Ishiguro, H.; Gong, J.; Patel, S.; Perchuk, A.; Meozzi, P.A.; Myers, L.; Mora, Z.; Tagliaferro, P.; Gardner, E.; et al. Discovery of the Presence and Functional Expression of Cannabinoid CB2 Receptors in Brain. Ann. N. Y. Acad. Sci. 2006, 1074, 514-536. [CrossRef] [PubMed]

115. Van Sickle, M.D.; Duncan, M.; Kingsley, P.J.; Mouihate, A.; Urbani, P.; Mackie, K.; Stella, N.; Makriyannis, A.; Piomelli, D.; Davison, J.S.; et al. Identification and Functional Characterization of Brainstem Cannabinoid CB2 Receptors. Science 2005, 310, 329-332. [CrossRef]

116. Cabral, G.A.; Raborn, E.S.; Griffin, L.; Dennis, J.; Marciano-Cabral, F. CB2 receptors in the brain: Role in central immune function. Br. J. Pharmacol. 2008, 153, 240-251. [CrossRef]

117. Rana, T.; Behl, T.; Sehgal, A.; Mehta, V.; Singh, S.; Kumar, R.; Bungau, S. Integrating Endocannabinoid Signalling In Depression. J. Mol. Neurosci. 2021, 2021, 1-13. [CrossRef]

118. Fitzgerald, M.L.; Shobin, E.; Pickel, V.M. Cannabinoid modulation of the dopaminergic circuitry: Implications for limbic and striatal output. Prog. Neuro Psychopharmacol. Biol. Psychiatry 2012, 38, 21-29. [CrossRef] [PubMed]

119. Lovinger, D.M.; Mathur, B.N. Endocannabinoids in striatal plasticity. Park. Relat. Disord. 2012, 18, S132-S134. [CrossRef]

120. Maldonado, R.; Cabañero, D.; Martín-García, E. The endocannabinoid system in modulating fear, anxiety, and stress. Dialog. Clin. Neurosci. 2020, 22, 229-239. [CrossRef]

121. Hwang, E.-S.; Kim, H.-B.; Lee, S.; Kim, M.-J.; Kim, K.-J.; Han, G.; Han, S.-Y.; Lee, E.-A.; Yoon, J.-H.; Kim, D.-O.; et al. Antidepressant-like effects of $\beta$-caryophyllene on restraint plus stress-induced depression. Behav. Brain Res. 2020, 380, 112439. [CrossRef]

122. Lazary, J.; Eszlari, N.; Juhasz, G.; Bagdy, G. A functional variant of CB2 receptor gene interacts with childhood trauma and FAAH gene on anxious and depressive phenotypes. J. Affect. Disord. 2019, 257, 716-722. [CrossRef]

123. Horder, J.; Harmer, C.J.; Cowen, P.J.; McCabe, C. Reduced neural response to reward following 7 days treatment with the cannabinoid CB1 antagonist rimonabant in healthy volunteers. Int. J. Neuropsychopharmacol. 2010, 13, 1103-1113. [CrossRef]

124. Sanchis-Segura, C.; Cline, B.H.; Marsicano, G.; Lutz, B.; Spanagel, R. Reduced sensitivity to reward in CB1 knockout mice. Psychopharmacology 2004, 176, 223-232. [CrossRef]

125. Gessa, G.; Melis, M.; Muntoni, A.; Diana, M. Cannabinoids activate mesolimbic dopamine neurons by an action on cannabinoid CB1 receptors. Eur. J. Pharmacol. 1998, 341, 39-44. [CrossRef]

126. Coccurello, R. Anhedonia in depression symptomatology: Appetite dysregulation and defective brain reward processing. Behav. Brain Res. 2019, 372, 112041. [CrossRef] [PubMed]

127. Rincón-Cortés, M.; Grace, A.A. Antidepressant effects of ketamine on depression-related phenotypes and dopamine dysfunction in rodent models of stress. Behav. Brain Res. 2020, 379, 112367. [CrossRef]

128. Ferber, S.G.; Roth, T.L.; Weller, A. Epigenetic fragility of the endocannabinoid system under stress: Risk for mood disorders and pharmacogenomic implications. Epigenomics 2020, 12, 657-660. [CrossRef] [PubMed]

129. Ferber, S.G.; Trezza, V.; Weller, A. Early life stress and development of the endocannabinoid system: A bidirectional process in programming future coping. Dev. Psychobiol. 2019. [CrossRef]

130. Lomazzo, E.; König, F.; Abassi, L.; Jelinek, R.; Lutz, B. Chronic stress leads to epigenetic dysregulation in the neuropeptide-Y and cannabinoid CB1 receptor genes in the mouse cingulate cortex. Neuropharmacology 2017, 113, 301-313. [CrossRef]

131. Hayase, T. Putative Epigenetic Involvement of the Endocannabinoid System in Anxiety- and Depression-Related Behaviors Caused by Nicotine as a Stressor. PLoS ONE 2016, 11, e0158950. [CrossRef] [PubMed]

132. Ruiz-Calvo, A.; Maroto, I.B.; Bajo-Grañeras, R.; Chiarlone, A.; Gaudioso, Á.; Ferrero, J.J.; Resel, E.; Sánchez-Prieto, J.; RodríguezNavarro, J.A.; Marsicano, G.; et al. Pathway-Specific Control of Striatal Neuron Vulnerability by Corticostriatal Cannabinoid CB1 Receptors-PubMed. Cereb. Cortex 2018, 28, 307-322. [CrossRef]

133. Monory, K.; Blaudzun, H.; Massa, F.; Kaiser, N.; Lemberger, T.; Schütz, G.; Wotjak, C.T.; Lutz, B.; Marsicano, G. Genetic Dissection of Behavioural and Autonomic Effects of $\Delta$ 9-Tetrahydrocannabinol in Mice. PLoS Biol. 2007, 5, e269. [CrossRef]

134. Hermann, H.; Marsicano, G.; Lutz, B. Coexpression of the cannabinoid receptor type 1 with dopamine and serotonin receptors in distinct neuronal subpopulations of the adult mouse forebrain. Neuroscience 2002, 109, 451-460. [CrossRef]

135. Centonze, D.; Battista, N.; Rossi, S.; Mercuri, N.B.; Finazzi-Agrò, A.; Bernardi, G.; Calabresi, P.; Maccarrone, M. A Critical Interaction between Dopamine D2 Receptors and Endocannabinoids Mediates the Effects of Cocaine on Striatal GABAergic Transmission. Neuropsychopharmacology 2004, 29, 1488-1497. [CrossRef]

136. Katona, I.; Freund, T.F. Multiple Functions of Endocannabinoid Signaling in the Brain. Annu. Rev. Neurosci. 2012, 35, 529-558. [CrossRef]

137. Bamford, N.S.; Zhang, H.; Schmitz, Y.; Wu, N.-P.; Cepeda, C.; Levine, M.S.; Schmauss, C.; Zakharenko, S.S.; Zablow, L.; Sulzer, D. Heterosynaptic Dopamine Neurotransmission Selects Sets of Corticostriatal Terminals. Neuron 2004, 42, 653-663. [CrossRef]

138. Kreitzer, A.C. Physiology and Pharmacology of Striatal Neurons. Annu. Rev. Neurosci. 2009, 32, 127-147. [CrossRef]

139. Castillo, P.E.; Younts, T.J.; Chávez, A.E.; Hashimotodani, Y. Endocannabinoid Signaling and Synaptic Function. Neuron 2012, 76, 70-81. [CrossRef] [PubMed]

140. Fernandez-Ruiz, J.; Moreno-Martet, M.; Rodríguez-Cueto, C.; Palomo-Garo, C.; Gómez-Cañas, M.; Valdeolivas, S.; Guaza, C.; Romero, J.; Guzmán, M.; Mechoulam, R.; et al. Prospects for cannabinoid therapies in basal ganglia disorders. Br. J. Pharmacol. 2011, 163, 1365-1378. [CrossRef] 
141. Blazquez, C.; Chiarlone, A.; Bellocchio, L.; Resel, E.; Pruunsild, P.; García-Rincón, D.; Sendtner, M.; Timmusk, T.; Lutz, B.; Galveroperh, I.; et al. The CB1 cannabinoid receptor signals striatal neuroprotection via a PI3K/Akt/mTORC1/BDNF pathway. Cell Death Differ. 2015, 22, 1618-1629. [CrossRef] [PubMed]

142. Mievis, S.; Blum, D.; Ledent, C. Worsening of Huntington disease phenotype in CB1 receptor knockout mice. Neurobiol. Dis. 2011, 42, 524-529. [CrossRef] [PubMed]

143. Chiarlone, A.; Bellocchio, L.; Blázquez, C.; Resel, E.; Soria-Gómez, E.; Cannich, A.; Ferrero, J.J.; Sagredo, O.; Benito, C.; Romero, J.; et al. A restricted population of CB1 cannabinoid receptors with neuroprotective activity. Proc. Natl. Acad. Sci. USA 2014, 111, 8257-8262. [CrossRef] [PubMed]

144. Shirayama, Y. Neurochemistry of the Nucleus Accumbens and its Relevance to Depression and Antidepressant Action in Rodents. Curr. Neuropharmacol. 2006, 4, 277-291. [CrossRef] [PubMed]

145. Belujon, P.; Grace, A.A. Regulation of dopamine system responsivity and its adaptive and pathological response to stress. Proc. $R$. Soc. B Biol. Sci. 2015, 282, 20142516. [CrossRef] [PubMed]

146. McEwen, B.S.; Morrison, J.H. The Brain on Stress: Vulnerability and Plasticity of the Prefrontal Cortex over the Life Course. Neuron 2013, 79, 16-29. [CrossRef] [PubMed]

147. Rademacher, D.J.; Hillard, C.J. Interactions between endocannabinoids and stress-induced decreased sensitivity to natural reward. Prog. Neuro Psychopharmacol. Biol. Psychiatry 2007, 31, 633-641. [CrossRef] [PubMed]

148. Dubreucq, S.; Matias, I.; Cardinal, P.; Häring, M.; Lutz, B.; Marsicano, G.; Chaouloff, F. Genetic Dissection of the Role of Cannabinoid Type-1 Receptors in the Emotional Consequences of Repeated Social Stress in Mice. Neuropsychopharmacology 2012, 37, 1885-1900. [CrossRef]

149. Knowland, D.; Lim, B.K. Circuit-based frameworks of depressive behaviors: The role of reward circuitry and beyond. Pharmacol. Biochem. Behav. 2018, 174, 42-52. [CrossRef] [PubMed]

150. Ottenheimer, D.; Richard, J.M.; Janak, P.H. Ventral pallidum encodes relative reward value earlier and more robustly than nucleus accumbens. Nat. Commun. 2018, 9, 1-14. [CrossRef]

151. Gardner, E.L. Addiction and Brain Reward and Antireward Pathways. Asthma Soc. Psychol. Factors Psychosom. Syndr. 2011, 30, 22-60. [CrossRef]

152. Smith, K.S.; Tindell, A.J.; Aldridge, J.W.; Berridge, K.C. Ventral pallidum roles in reward and motivation. Behav. Brain Res. 2009, 196, 155-167. [CrossRef]

153. Bracci, E.; Centonze, D.; Bernardi, G.; Calabresi, P. Dopamine Excites Fast-Spiking Interneurons in the Striatum. J. Neurophysiol. 2002, 87, 2190-2194. [CrossRef]

154. Laurikainen, H.; Tuominen, L.; Tikka, M.; Merisaari, H.; Armio, R.-L.; Sormunen, E.; Borgan, F.; Veronese, M.; Howes, O.; Haaparanta-Solin, M.; et al. Sex difference in brain CB1 receptor availability in man. Neuroimage 2019, 184, 834-842. [CrossRef]

155. Akil, H.; Gordon, J.; Hen, R.; Javitch, J.; Mayberg, H.; McEwen, B.; Meaney, M.J.; Nestler, E.J. Treatment resistant depression: A multi-scale, systems biology approach. Neurosci. Biobehav. Rev. 2018, 84, 272-288. [CrossRef] [PubMed]

156. Gaynes, B.N.; Warden, D.; Trivedi, M.H.; Wisniewski, S.R.; Fava, M.; Rush, A.J. What Did STAR*D Teach Us? Results From a Large-Scale, Practical, Clinical Trial for Patients With Depression. Psychiatr. Serv. 2009, 60, 1439-1445. [CrossRef] [PubMed]

157. Katz, M.M.; Tekell, J.L.; Bowden, C.L.; Brannan, S.; Houston, J.P.; Berman, N.; Frazer, A. Onset and Early Behavioral Effects of Pharmacologically Different Antidepressants and Placebo in Depression. Neuropsychopharmacology 2003, 29, 566-579. [CrossRef] [PubMed]

158. Spijker, J.; Bijl, R.V.; De Graaf, R.; Nolen, W.A. Determinants of poor 1-year outcome of DSM-III-R major depression in the general population: Results of the Netherlands Mental Health Survey and Incidence Study (NEMESIS). Acta Psychiatr. Scand. 2001, 103, 122-130. [CrossRef] [PubMed]

159. Berridge, K.C.; Kringelbach, M.L. Pleasure Systems in the Brain. Neuron 2015, 86, 646-664. [CrossRef]

160. Martin-Soelch, C. Is depression associated with dysfunction of the central reward system? Biochem. Soc. Trans. 2009, 37, 313-317. [CrossRef] [PubMed]

161. Shbiro, L.; Hen-Shoval, D.; Hazut, N.; Rapps, K.; Dar, S.; Zalsman, G.; Mechoulam, R.; Weller, A.; Shoval, G. Effects of cannabidiol in males and females in two different rat models of depression. Physiol. Behav. 2019, 201, 59-63. [CrossRef]

162. Shoval, G.; Shbiro, L.; Hershkovitz, L.; Hazut, N.; Zalsman, G.; Mechoulam, R.; Weller, A. Prohedonic Effect of Cannabidiol in a Rat Model of Depression. Neuropsychobiology 2016, 73, 123-129. [CrossRef]

163. Nutt, D.J.; Demyttenaere, K.; Janka, Z.; Aarre, T.; Bourin, M.; Canonico, P.L.; Carrasco, J.L.; Stahl, S. The other face of depression, reduced positive affect: The role of catecholamines in causation and cure. J. Psychopharmacol. 2006, 21, 461-471. [CrossRef]

164. McCabe, C.; Cowen, P.J.; Harmer, C.J. Neural representation of reward in recovered depressed patients. Psychopharmacology 2009, 205, 667-677. [CrossRef] [PubMed]

165. Prisco, S.; Esposito, E. Differential effects of acute and chronic fluoxetine administration on the spontaneous activity of dopaminergic neurones in the ventral tegmental area. Br. J. Pharmacol. 1995, 116, 1923-1931. [CrossRef] [PubMed]

166. Di Mascio, M.; Di Giovanni, G.; Di Matteo, V.; Prisco, S.; Esposito, E. Selective serotonin reuptake inhibitors reduce the spontaneous activity of dopaminergic neurons in the ventral tegmental area. Brain Res. Bull. 1998, 46, 547-554. [CrossRef]

167. Dremencov, E.; El Mansari, M.; Blier, P. Effects of sustained serotonin reuptake inhibition on the firing of dopamine neurons in the rat ventral tegmental area. J. Psychiatry Neurosci. 2009, 34, 223-229. [PubMed] 
168. Juckel, G.; Schlagenhauf, F.; Koslowski, M.; Filonov, D.; Wüstenberg, T.; Villringer, A.; Knutson, B.; Kienast, T.; Gallinat, J.; Wrase, J.; et al. Dysfunction of ventral striatal reward prediction in schizophrenic patients treated with typical, not atypical, neuroleptics. Psychopharmacology 2006, 187, 222-228. [CrossRef]

169. Schlagenhauf, F.; Sterzer, P.; Schmack, K.; Ballmaier, M.; Rapp, M.; Wrase, J.; Juckel, G.; Gallinat, J.; Heinz, A. Reward Feedback Alterations in Unmedicated Schizophrenia Patients: Relevance for Delusions. Biol. Psychiatry 2009, 65, 1032-1039. [CrossRef]

170. Seeman, P. Atypical Antipsychotics: Mechanism of Action. Can. J. Psychiatry 2002, 47, 29-40. [CrossRef]

171. Belujon, P.; Jakobowski, N.L.; Dollish, H.K.; A Grace, A. Withdrawal from Acute Amphetamine Induces an Amygdala-Driven Attenuation of Dopamine Neuron Activity: Reversal by Ketamine. Neuropsychopharmacology 2015, 41, 619-627. [CrossRef]

172. Norris, C.; Loureiro, M.; Kramar, C.; Zunder, J.; Renard, J.; Rushlow, W.; LaViolette, S.R. Cannabidiol Modulates Fear Memory Formation Through Interactions with Serotonergic Transmission in the Mesolimbic System. Neuropsychopharmacology 2016, 41, 2839-2850. [CrossRef] [PubMed]

173. Seeman, P. Cannabidiol is a partial agonist at dopamine D2High receptors, predicting its antipsychotic clinical dose. Transl. Psychiatry 2016, 6, e920. [CrossRef] [PubMed]

174. Campos, A.C.; Moreira, F.A.; Gomes, F.V.; Del Bel, E.A.; Guimarães, F.S. Multiple mechanisms involved in the large-spectrum therapeutic potential of cannabidiol in psychiatric disorders. Philos. Trans. R. Soc. B Biol. Sci. 2012, 367, 3364-3378. [CrossRef] [PubMed]

175. Gururajan, A.; Buuse, M.V.D. Is the mTOR-signalling cascade disrupted in Schizophrenia? J. Neurochem. 2014, $129,377-387$. [CrossRef] [PubMed]

176. Liu, Y.; Pham, X.; Zhang, L.; Chen, P.-L.; Burzynski, G.M.; McGaughey, D.M.; He, S.; McGrath, J.A.; Wolyniec, P.S.; Fallin, M.D.; et al. Functional Variants in DPYSL2 Sequence Increase Risk of Schizophrenia and Suggest a Link to mTOR Signaling. G3 Genes Genomes Genet. 2015, 5, 61-72. [CrossRef] [PubMed]

177. Renard, J.; Loureiro, M.; Rosen, L.G.; Zunder, J.; De Oliveira, C.; Schmid, S.; Rushlow, W.J.; LaViolette, S.R. Cannabidiol Counteracts Amphetamine-Induced Neuronal and Behavioral Sensitization of the Mesolimbic Dopamine Pathway through a Novel mTOR/p70S6 Kinase Signaling Pathway. J. Neurosci. 2016, 36, 5160-5169. [CrossRef]

178. Russo, E.B.; Burnett, A.; Hall, B.; Parker, K.K. Agonistic Properties of Cannabidiol at 5-HT1a Receptors. Neurochem. Res. 2005, 30, 1037-1043. [CrossRef]

179. Bisogno, T.; Hanuš, L.; De Petrocellis, L.; Tchilibon, S.; E Ponde, D.; Brandi, I.; Moriello, A.S.; Davis, J.B.; Mechoulam, R.; Di Marzo, V. Molecular targets for cannabidiol and its synthetic analogues: Effect on vanilloid VR1 receptors and on the cellular uptake and enzymatic hydrolysis of anandamide. Br. J. Pharmacol. 2001, 134, 845-852. [CrossRef]

180. Hudson, R.; Rushlow, W.; LaViolette, S.R. Phytocannabinoids modulate emotional memory processing through interactions with the ventral hippocampus and mesolimbic dopamine system: Implications for neuropsychiatric pathology. Psychopharmacology 2018, 235, 447-458. [CrossRef]

181. Kusmider, M.; Faron-Górecka, A.; Solich, J.; Pabian, P.; Dziedzicka-Wasylewska, M. Time-course of changes in key catecholaminergic receptors and trophic systems in rat brain after antidepressant administration. Neurochem. Int. 2020, 141, 104885. [CrossRef]

182. Salort, G.; Hernández-Hernández, E.; García-Fuster, M.J.; García-Sevilla, J.A. Regulation of cannabinoid CB1 and CB2 receptors, neuroprotective mTOR and pro-apoptotic JNK1/2 kinases in postmortem prefrontal cortex of subjects with major depressive disorder. J. Affect. Disord. 2020, 276, 626-635. [CrossRef]

183. Xue, S.-S.; Xue, F.; Ma, Q.-R.; Wang, S.-Q.; Wang, Y.; Tan, Q.-R.; Wang, H.-N.; Zhou, C.-H.; Peng, Z.-W. Repetitive high-frequency transcranial magnetic stimulation reverses depressive-like behaviors and protein expression at hippocampal synapses in chronic unpredictable stress-treated rats by enhancing endocannabinoid signaling. Pharmacol. Biochem. Behav. 2019, $184,172738$. [CrossRef]

184. Shuto, T.; Kuroiwa, M.; Sotogaku, N.; Kawahara, Y.; Oh, Y.-S.; Jang, J.-H.; Shin, C.-H.; Ohnishi, Y.N.; Hanada, Y.; Miyakawa, T.; et al. Obligatory roles of dopamine D1 receptors in the dentate gyrus in antidepressant actions of a selective serotonin reuptake inhibitor, fluoxetine. Mol. Psychiatry 2020, 25, 1229-1244. [CrossRef] [PubMed]

185. Arnsten, A.F.T. Stress weakens prefrontal networks: Molecular insults to higher cognition. Nat. Neurosci. 2015, 18, 1376-1385. [CrossRef] [PubMed] 